\title{
Area of Mutual InTEREST AgreEMENTS AND CANADIAN COMPETITION LAW CONSIDERATIONS
}

\author{
FRANK ALEXANDER ${ }^{*}$ AND ERIK ARNOLD ${ }^{* *}$
}

Area of Mutual Interest Agreements (AMIAs) are a common feature within the Canadian oil and gas industry. These agreements are usually entered into for the purposes of sharing technical information between two or more parties. This article explores the implications of the various types of AMIAs in relation to the Competition Act. While there is essentially no applicable Canadian case law on the subject, this article examines the potential civil and criminal penalties that the Competition Act may impose. In addition to detailing the statutory landscape in Canada, this article looks at how this issue has unfolded in the United States.

\section{TABLE OF CONTENTS}

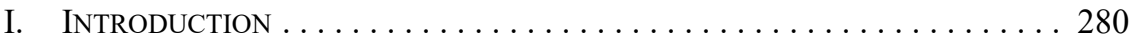

II. AN ANALYSIS OF DIFFERENT TYPES OF AREA

of Mutual Interest AgreEMENTS . . . . . . . . . . . . . . . . 282

A. Circumstances Where an AMiA is Often ApPlicable . . . . . . 282

B. OBSERVATIONS REGARDING AMIAS IN THE

INTERNATIONAL PETROLEUM INDUSTRY MARKETPLACE . . . . . . . 283

C. The Fundamental Distinction Between Non-Compete

AMIAs and AMIAs that ESSENTIALly PROVIDE EACH PARTY

WITH THE RIGHT TO ATTEMPT TO EXPLOIT AN OPPORTUNITY . . . . . 284

D. The Fundamental Distinctions BetweEn Up-Front

AMIAS AND AFTER THE FACT AMIAS . . . . . . . . . . . . 284

E. DEFINITION OF "OPPORTUNITY" ................... 286

F. NO NON-COMPETE . . . . . . . . . . . . . . . . . 286

G. The Trigger For a PARTy's Obligation to Provide Notice of AN APPLICABLE OPPORTUNITY TO EACH Other PARTy . . . . . . 287

H. Contents of Invitation to Participate . . . . . . . . . . . . . . 288

I. Provisions Providing For Good FAith DUty . . . . . . . . . 288

J. Procedure For Finalizing EACH OfFER/ACCEPTANCE to Be TRANSMitTED to the APPLICABle THIRd PARTY . . . . . . . . 289

K. HOW Disputes Over COMMERCIAl TERMS AND OtHER Material Provisions are Resolved . . . . . . . . . . . . . . 290

L. Parties Electing Not to Proceed with an

OFFER/ACCEPTANCE ARE Prohibited From MaKING AN

OfFER/ACCEPTANCE FOR A StiPUlated PeRIOd of TIME . . . . . . 292

M. OfFER/ACCEPTANCE COORDINATOR . . . . . . . . . . . . . 292

N. Negotiation Costs . . . . . . . . . . . . . . . . . . . . . . . 292

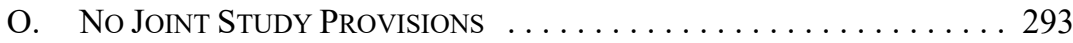

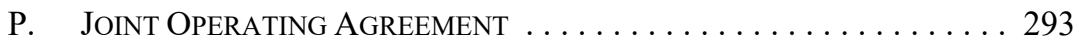

* $\quad$ Partner, Dentons Canada LLP

Associate, Dentons Canada LLP. The authors wish to extend a special thanks to Kim Martyn of Dentons Canada LLP for her extensive assistance with the preparation of this article. The Canadian Energy Law Foundation does not necessarily endorse the contents or the opinions presented in this article. 
Q. REMEDIES FOR BREACH OF OBLIGATION TO

Provide InVITATION TO PARTICIPATE . . . . . . . . . . . . . . . . . . . 294

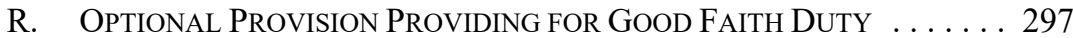

S. Affiliate Compliance . . . . . . . . . . . . . . . . . . . . . . 297

T. WARranties Regarding Similar AgreEMENTS . . . . . . . . . . . 297

U. EXCLUSION OF CORPORATE ACQUISITIONS . . . . . . . . . . . . . 298

III. CANADIAN COMPETITION LAW CONSIDERATIONS . . . . . . . . . . . . . . . . 298

A. Introduction . . . . . . . . . . . . . . . . . . . . . . 298

B. OVERVIEW of CANADIAN COMPETITION LAW . . . . . . . . . . . 300

C. SECTION 45: CONSPIRACIES, AGREEMENTS, OR

ARRANGEMENTS BETWEEN COMPETITORS . . . . . . . . . 301

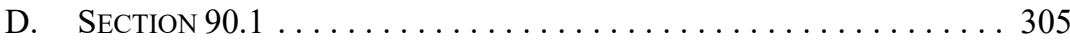

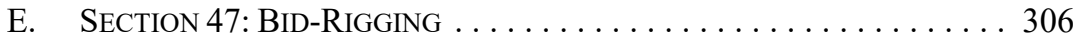

F. Conclusions ............................. . . 309

\section{INTRODUCTION}

This article examines area of mutual interest agreements (AMIAs) that are employed by oil companies around the world, and the Canadian competition law implications pertinent to the use of AMIAs in Canada.

The impetus for entering into an AMIA is usually the sharing of technical information by one oil company with another oil company.

An oil company that has participated in (and borne a share of the cost of) petroleum operations (such as seismic and drilling programs) in a given area will generally enjoy a competitive advantage over other oil companies in regard to the area by way of the technical information that is generated as a result of such operations. This technical information would generally provide the oil company with a better understanding of the geological prospectivity of not only the area itself, but also larger areas that are contiguous with, and in relative proximity to, the area. The disclosing oil company would often, as part of any sharing of such technical information with another oil company, wish to bind the other oil company to an AMIA in regard to a designated area of mutual interest (AMI) that such technical information would reasonably be applicable to.

By way of entering into such an AMIA, the oil company receiving the technical information would essentially agree to condition the rights that it would otherwise have to obtain exploration, development, and production rights within the applicable AMI.

There are essentially three genres of AMIAs used in the international petroleum industry (including in Canada). ${ }^{1}$

Preparing this article, over 100 example AMIAs used by oil companies in the international petroleum industry worldwide (including in Canada) were reviewed. Based upon that review, it would appear that the majority of AMIAs used by oil companies internationally (including in Canada) are after the fact AMIAs (After the Fact AMIAs), while a strong minority are up-front AMIAs (Up-Front AMIAs) (colleagues working in the UK North Sea advise that Up-Front AMIAs are used almost exclusively in that area). Only a small fraction of the AMIAs used in the world appear to be non-compete AMIAs (Non-Compete AMIAs). 
One such genre is the Non-Compete AMIA. Under a Non-Compete AMIA, an oil company that receives technical information from another oil company would be prohibited from obtaining exploration, development, and production rights within the applicable AMI without first obtaining the consent of such other oil company.

The second genre is the Up-Front AMIA. Under an Up-Front AMIA, each oil company party would itself have the right to attempt to obtain exploration, development, and production rights within the AMI from the applicable third party (host government entity or oil company) that holds such exploration, development, and production rights (Applicable Third Party). At the same time, however, each party would essentially be obligated to give each other party, "before the fact," the option to jointly participate with such party in any such attempt (subject to any applicable consents or waivers being obtained from the host government or from any applicable third party oil company). Up-Front AMIAs usually provide for a mechanism to resolve any disputes over what terms and conditions would be submitted, by way of an applicable offer or acceptance, to the Applicable Third Party.

The third genre of AMIA is the After the Fact AMIA. By way of contrast with an UpFront AMIA, under an After the Fact AMIA each party would itself have the right to attempt to obtain exploration, development, and production rights within the AMI without first even notifying each other party. At the same time, a party that obtained exploration, development, and production rights within the AMI would be obligated to give each other party the option to jointly participate with such party in exploration, development, and production rights (but only "after the fact" and subject to any applicable consents or waivers being obtained from the host government or from any applicable third party oil company).

Companies operating in Canada who are considering whether or not to enter into an AMIA should be cognizant of the operation of the Competition Act. ${ }^{2}$ Sanctions under the Competition Act include potential criminal liability for bid-rigging, which could result in fines and prison time, as well as the authority of the Canadian Competition Bureau to review agreements among competitors and pursue prohibition orders in respect of the same.

There is essentially no applicable Canadian case law on this point. It is, however, our view that on the basis of the Canadian Competition Act, and on the basis of illustrative US case law:

(1) As a general proposition, a Non-Compete AMIA would likely be legally characterized as producing a restraint on competition, and would likely be determined to be per se illegal — creating potential exposure to civil sanctions but would likely not attract criminal sanctions. However, if the Non-Compete AMIA included language contemplating potential collaboration on attempts to exploit opportunities within the AMI going forward (even on the basis that one or more of the parties would itself have no right to attempt to exploit an opportunity without the consent of one or more of the other parties) then such Non-Compete AMIA would likely be considered to be legally permissible under Canadian competition law. This is because such an arrangement may result in prospective 
joint ventures. Accordingly, the Canadian Competition Bureau would likely not exercise its authority to pursue a prohibition order, and such a Non-Compete AMIA would likely not create exposure even to civil sanctions.

(2) In contrast to a Non-Compete AMIA, it would be less likely for an Up-Front AMIA or an After the Fact AMIA to be legally characterized as producing a restraint on competition and be determined to be per se illegal. This is because each of them essentially provides for each party to itself have the right to attempt to exploit each opportunity within the AMI. Also, even if an Up-Front AMIA or an After the Fact AMIA were to be legally characterized as producing a restraint on competition and, as a result, be determined to be per se illegal — each would likely be determined to be legally permissible under Canadian competition law. This is because both such genres provide for potential collaboration on attempts to exploit opportunities within the AMI going forward and, as such, each of them may result in prospective joint ventures. Accordingly, the use of either an Up-Front AMIA or an After the Fact AMIA would likely not become subject to a prohibition order or create exposure even to civil sanctions.

\section{AN ANALYSIS OF DifFERENT TYPES OF AREA OF MUTUAL INTEREST AGREEMENTS}

\section{A. Circumstances Where an AMIA is Often Applicable}

Oil companies often choose to employ an AMIA in circumstances such as the following:

(1) In conjunction with a Joint Operating Agreement (JOA) under which multiple oil companies would be jointly conducting, and sharing the cost of, petroleum operations which will generate technical information. In such a case the associated AMIA would normally include the contract area associated with the JOA, and would often also include an additional area (outside of, but contiguous to, such JOA contract area) that is, at least ostensibly, geologically related (in aggregate, the AMI). In view of the cost sharing of the generation of information under the JOA, a reciprocal AMIA (where the AMI obligation would attach to all JOA parties uniformly) would usually be applicable in such a case.

(2) In conjunction with a confidentiality agreement where an oil company, in conjunction with an effort to farmout or otherwise to transfer an interest in a government petroleum contract, such as a production sharing contract, or any lease or licence as applicable (in Canada, by way of a Crown lease), which grants exploration, development, and production rights (Government Petroleum Contract or GPC $)^{3}$ - along with the applicable interest in any associated JOA — discloses confidential information to another oil company for the purpose of permitting the other oil company to evaluate the applicable opportunity (Opportunity). In such a case the associated AMIA would normally include the contract area of the production rights may be owned, and granted to oil companies, by private right holders. 
applicable GPC (in the context of prospective relinquishments), and might also include an additional area (outside of, but contiguous to, such contract area) that is, at least ostensibly, geologically related. Assuming that there is no cost sharing in regard to the disclosed information, a non-reciprocal AMIA (where the AMI obligation would attach only to the oil company receiving the applicable information) would usually be applicable in such a case.

(3) In conjunction with a farmout agreement, or a sale and purchase agreement, either of which might also involve a JOA, where an oil company is transferring a portion, but not all, of its interest in a GPC to another oil company. In such a case the associated AMIA would normally include the contract area of the applicable GPC (in the context of prospective relinquishments), and might also include an additional area (outside of, but contiguous to, such contract area) that is, at least ostensibly, geologically related. A reciprocal AMIA (where the AMI obligation would attach to each of the parties uniformly), would usually be applicable in such a case. This is in view of: (a) the consideration paid by the farmee or transferee for the GPC interest being transferred (resulting in both oil companies having shared the cost of the applicable technical information); and (b) going forward, the sharing of the cost of the generation of addition information under the associated JOA. In such a case the applicable oil companies would usually provide that any pre-existing nonreciprocal AMIA agreement between them (such as one entered into in connection with a confidentiality agreement by way of circumstances described in (2), above), would be replaced by such a new reciprocal AMIA.

\section{B. ObSERVATIONS REgarding AMIAS IN THE International Petroleum Industry MarketPlace}

Preparing this article, a review was made of: (1) a large number of example AMIAs in the international petroleum industry; ${ }^{4}(2)$ the body of literature regarding AMIAs; and (3) example disputes between oil companies pertinent to AMIAs. On the basis of such review it was clear that:

(1) aside from "Non-Compete AMIAs," there are "Up-Front AMIAs" and "After the Fact AMIAs";

(2) there are a wide range of variations within each such genre;

(3) many AMIAs do a woeful job of providing for the rights and obligations of the respective parties; and

(4) there is a paucity of helpful articles regarding AMIAs. ${ }^{7}$

\footnotetext{
Supra note 1.

See Part II.C, below.

See Frank Alexander, Adam Horne \& Chad Roth, "International Area of Mutual Agreements (“AMIs")

- Two Basic Genres," The AIPN Advisor (December 2008).

See Part III.B, below. There is also no Canadian case law considering the application of Canadian competition law to AMIAs.
} 
It is also clear that many oil companies tend to take much more care in the preparation of, for example, a JOA (regarding the relationship of such oil company with other applicable oil companies in regard to an applicable GPC) - than they do in the preparation of an AMIA. This is in spite of the fact that an AMIA might be critical to the determination of whether or not an oil company will, in the first place, have a right to an interest in an applicable GPC.

\section{The Fundamental Distinction Between Non-Compete AMiAs and AMIAs that Essentially Provide Each Party With the Right TO ATTEMPT TO EXPLOIT AN OPPORTUNITY}

Non-Compete AMIAs essentially prohibit a party from attempting to obtain an interest in a GPC located within the AMI without the consent of at least one of the other parties to the Non-Compete AMIA.

An Up-Front AMIA, by way of contrast, essentially provides each party with a right to participate in any attempt to exploit an interest in a GPC located within the AMI. ${ }^{8}$ This is dependent on each party being willing to participate on the basis of the terms and conditions submitted to the Applicable Third Party (by way of an applicable offer or acceptance), which would be determined in accordance with the Up-Front AMIA.

An After the Fact AMIA, unlike the case of an Up-Front AMIA, permits each party to proceed in an attempt to exploit without even notifying other parties to the After the Fact AMIA. ${ }^{9}$ Non-Compete AMIAs generally constitute a greater risk from a competition law perspective than Up-Front AMIAs and After the Fact AMIAs. ${ }^{10}$

\section{The Fundamental Distinctions Between UP-Front AMIAS AND AFTER THE FACT AMIAS}

In basic terms, a party under an Up-Front AMIA (the form most often used in jurisdictions such as the North Sea) is required to notify each other party to the Up-Front AMIA (subject to obtaining any necessary consents pertinent to any applicable confidentiality obligations) prior to such party making any attempt to exploit an Opportunity located within an AMI. This is in order to give each other party the option to jointly participate in the attempt to exploit the Opportunity (subject to any applicable consents or waivers being obtained under the applicable GPC and under any applicable JOA).

Examples of Up-Front AMIAs include: (1) "study and bid agreements" (SBAs), including the AIPN's Study and Bid Group Agreement (2006); (2) certain "joint study agreements" which provide for an "operator" to conduct a joint study and, if applicable, to make a bid or proposal and conduct negotiations (the costs of which are shared by the applicable oil companies).

See Part II.D, below.

Ibid.

Canadian competition law considerations associated with AMIAs are further described in Part III, below. Association of International Petroleum Negotiators, Study and Bid Group Agreement (2006) (Houston, AIPN, 2006), online: <https://www.aipn.org/mcvisitors.aspx > [AIPN Model SBA]. 
Whereas SBAs are employed in the context of host government competitive bid rounds, the subject of a "joint study agreement" may be a geographical area which may become the subject of a GPC by way of "direct negotiations" between applicable oil companies and the applicable host government (sometimes such "joint study agreement" arrangements may be associated with a "technical evaluation agreement" (TEA) entered into between applicable oil companies and a host government).

By way of contrast, under an After the Fact AMIA, only after a party has successfully exploited an Opportunity would such party be obligated to notify (subject to any necessary consents, in the context of any applicable confidentiality obligations, being obtained) each other party to the After the Fact AMIA of the Opportunity. This is in order to give each such other party the option to attempt to join such party in the Opportunity (subject to any necessary consents or waivers being obtained from the host government or applicable third party oil companies in the context of an applicable transfer of interest from such party to each applicable other party).

An Up-Front AMIA would generally be attractive to any party that believed that there would be as much, or more, potential that another party to the applicable Up-Front AMIA would be exposed to Opportunities, as there would be potential that such party would be exposed to Opportunities. Application of an Up-Front AMIA would provide such a party with the right to participate "up-front," with the party that was exposed to an Opportunity in all aspects of any attempt to exploit that Opportunity. This includes the making of decisions pertinent to the content of offers or acceptances submitted to an Applicable Third Party pertinent to an applicable Opportunity.

Also, under an Up-Front AMIA each party would essentially have the right to participate in any attempt to exploit an Opportunity located within the AMI "shoulder to shoulder" with each other party that wished to participate. If an applicable host government, or any applicable oil companies, wanted one of the parties, then that might make it more likely that they would provide required consents or waivers permitting each other party to participate in the exploitation of the Opportunity - than would otherwise be the case (such as, for example, in the case of application of an After the Fact AMIA).

An After the Fact AMIA would generally be more attractive to an oil company that believed that there would be more potential that it would be exposed to Opportunities than there would be potential that another party to the applicable AMIA would be exposed to Opportunities. Application of an After the Fact AMIA would provide such a party with the right to attempt to exploit an Opportunity without even having to notify each other party of the existence of the Opportunity. Accordingly, it would have the right to exert absolute control over all aspects of the attempt to exploit the Opportunity. This includes the making of decisions pertinent to the content of offers or acceptances submitted to an Applicable Third Party in regard to an applicable Opportunity.

Also, under an After the Fact AMIA a party would, if it wished to share the applicable costs and risks associated with an Opportunity and to share resources with other parties, have the option of inviting one or more of the other parties to join such party in the attempt to exploit the Opportunity. 
Finally, under an After the Fact AMIA, assuming that a party chose to attempt to exploit an applicable Opportunity on its own, there would perhaps be a greater likelihood that such party would end up not having to share the exploited Opportunity with each other party than would be the case under an Up-Front AMIA. Firstly, none of the other parties would have had the opportunity to participate with such party in the making of decisions pertinent to the content of offers or acceptances submitted to an Applicable Third Party in regard to an Opportunity. Accordingly, it might be more likely, than would otherwise be the case, that the terms and conditions associated with an exploited Opportunity would not be attractive to the other parties. Secondly, it might possibly not be as likely, in the case of an After the Fact AMIA, that the applicable host government, or any applicable oil companies, would grant necessary consents or any applicable waiver rights that would permit the participation of such other parties - as it would have been that they would have granted applicable consents or waivers in the context of each non-Opportunity, having participated in the original attempt to exploit the Opportunity "shoulder to shoulder" with the party under an Up-Front AMIA. ${ }^{12}$

The following describes some of the concepts, and associated language, that may be found in an Up-Front AMIA.

\section{E. DEFINITION OF "OPPORTUNITY"}

The definition of "Opportunity" in an Up-Front AMIA might be along the lines of the following:

Opportunity means an opportunity to enter into a GPC, where any portion of the contract area of such GPC is located within the AMI, including, if applicable, ownership of associated assets provided for under the applicable GPC (or under any associated joint operating agreement), such as pipelines, whether or not within the AMI.

\section{F. NO NON-COMPETE}

It would not be appropriate to include in an Up-Front AMIA a non-compete provision (providing, for example, that a party may not attempt to exploit an Opportunity without the consent of at least one other party). As in the case of the AIPN Model SBA, ${ }^{13}$ in an Up-Front AMIA each party essentially has the right to participate in an attempt to exploit an applicable Opportunity without obtaining the consent of any other party.

Such a right would be, however, conditioned upon the party agreeing to proceed in any such attempt to exploit an applicable Opportunity on the basis of an "Offer/Acceptance" (defined below) transmitted to an Applicable Third Party containing Commercial Terms ${ }^{14}$

12 As indicated above, if an applicable host government, or any applicable third party oil company, wanted one of the parties, then that might make it more likely that they would provide required consents or waivers permitting each other party to participate in the exploitation of the Opportunity "up-front" under an Up-Front AMIA than would otherwise be the case (such as, for example, in the case of application of an After the Fact AMIA). Commercial Terms is defined below at 290 . 
and Other Material Provisions ${ }^{15}$ determined in accordance with the procedures described in the Up-Front AMIA.

In this connection, Up-Front AMIAs usually provide for mechanisms to resolve any failure of the parties who wish to participate in the attempt to exploit an applicable Opportunity unanimously to agree upon the Commercial Terms or Other Material Provisions to be included in an applicable Offer/Acceptance. ${ }^{16}$

\section{G. The Trigger for a Party's Obligation to Provide Notice of an ApPlicable OpPortunity to EACH Other Party}

A review of example Up-Front AMIAs indicate that there are a significant range of approaches in regard to when a party's obligation to give notice to each other party of an applicable Opportunity would arise. These range from the time at which such party itself becomes aware of an Opportunity to the time prior to taking action to exploit an Opportunity, such as by way of making, or giving, an Offer/Acceptance. Intermediate approaches include the requirement that such party must give such notice prior to signing a confidentiality agreement in regard to an Opportunity and the time when such party has itself made a decision that it will attempt to exploit the Opportunity.

Some Up-Front AMIAs implement an approach whereby a party (Opportunity Party) must, in regard to each Opportunity for which such party wishes to transmit an Offer/Acceptance, first provide an invitation to participate (Invitation to Participate) to each other party (non-Opportunity Party). ${ }^{17}$ The Invitation to Participate is the first step in the determination of the Commercial Terms and Other Material Provisions to be contained in any such Offer/Acceptance. It is on the basis of such Offer/Acceptance that each party shall make its own determination whether or not to participate in the attempt to exploit an applicable Opportunity. ${ }^{18}$

In contrast, some Up-Front AMIAs implement an approach whereby a party must, separate from its obligations if it wished to transmit an Offer/Acceptance in regard to an Opportunity, issue a notification to each other party prior to such party submitting a request for a "bid package," or executing a confidentiality agreement, in regard to an Opportunity. Such notification would include a description that would permit each other party to reasonably understand the nature of the Opportunity that would be the subject of the "bid package" or confidentiality agreement — but would not necessarily provide each other party with the right to participate with such party in any such "bid package" or confidentiality agreement. The Opportunity party, and each non-Opportunity party, would, however, be free mutually to agree to collaborate with one another in regard to any such "bid package" or confidentiality agreement.

Other Material Provisions is defined below at 290.

See Part II.K, below.

The contents of the Invitation to Participate are described immediately below.

The same is the case in regard to any Offer/Acceptance made subsequent to the original Offer/Acceptance, as part of any applicable negotiation process. 
Some Up-Front AMIAs may also provide that if the terms of any such "bid package" or confidentiality agreement would: (1) prevent the Opportunity Party from disclosing to each non-Opportunity Party information regarding the Opportunity without the requirement of first having to obtain the consent of the Applicable Third Party; or (2) prevent a nonOpportunity Party from participating in the Opportunity, then in either such case any offer or acceptance pertaining to such "bid package" or confidentiality agreement shall be deemed to be an Offer/Acceptance that would require the Opportunity Party to provide an Invitation to Participate to each non-Opportunity Party. This is for the purpose of preventing a party from circumventing the primary purpose of the Up-Front AMIA — which is essentially to afford each party with the opportunity to participate in any attempt to exploit an Opportunity "up-front."

Such an Invitation to Participate would be the first step in a procedure according to which the terms to be included in any such offer or acceptance pertinent to such "bid package" or confidentiality agreement would be determined. Such a procedure would be a mutatis mutandis version of the procedure, described below, according to which the Commercial Terms and Other Material Provisions to be contained in an Offer/Acceptance would be determined.

\section{H. Contents of Invitation to Participate}

An Up-Front AMIA may provide that an Invitation to Participate in regard to each Opportunity for which an Opportunity Party wishes to transmit an Offer/Acceptance to an Applicable Third Party shall set forth in reasonable detail (to the extent known by such party) a description of the Opportunity reasonably adequate to permit each party to make an informed decision whether or not to participate in an attempt to exploit the Opportunity. This obligation would be subject to any applicable confidentiality obligation of the Opportunity Party to an Applicable Third Party. It may also be provided that the Opportunity Party shall make reasonable efforts, prior to providing the Invitation to Participate, to obtain any applicable consents necessary to disclose such information to each non-Opportunity Party. Some Up-Front AMIAs provide that in no event shall a party have any obligation to disclose: (1) applicable data in possession of such party; or (2) such party's own internal analyses (including fiscal, contractual, legal, technical, or political risk analyses).

Usually there is a requirement that the Invitation to Participate include a description of the Commercial Terms and Other Material Provisions that the Opportunity Party would wish to see included in the Offer/Acceptance. There is also usually a requirement that the Invitation to Participate include notice of a meeting where each other party interested in the Opportunity would have the opportunity to communicate its own proposals regarding such Commercial Terms and Other Material Provisions.

\section{Provisions Providing for Good Faith Duty}

It might be difficult for each non-Opportunity Party to verify whether or not the Opportunity Party had indeed made reasonable efforts to obtain any such necessary consents in order to permit the Opportunity Party to issue the Invitation to Participate to each NonOpportunity Party. Accordingly, some Up-Front AMIAs provide for the Opportunity Party 
to have a good faith duty in this specific regard. Some other Up-Front AMIAs provide for a generalized good faith duty generally applicable to performance under the Up-Front AMIA.

It should be considered, however, that even if an Up-Front AMIA does not provide for a duty of good faith, such a duty may nevertheless be imputed by way of the governing law applicable to the Up-Front AMIA.

\title{
J. Procedure For FinAlizing EACH OfFER/ACCEPTANCE TO BE Transmitted to the Applicable Third Party
}

\author{
An Up-Front AMIA might define “Offer/Acceptance” as follows:
}

Offer/Acceptance means either of the following made, or given, by a party to an Applicable Third Party with the objective of obtaining either: (i) an interest in an Opportunity such as by way of any applicable: GPC; sale and purchase agreement; farmout agreement; joint operating agreement; or other agreement pertaining to the exploitation of an Opportunity; (ii) an option to obtain an interest in an Opportunity; or (iii) an exclusive right to negotiate for either an interest in an Opportunity or for an option to obtain an interest in an Opportunity:

(i) any applicable offer, whether binding or non-binding, conditional or unconditional (including by way of a proposed term sheet, memorandum of understanding, or letter of intent); or

(ii) any applicable acceptance of an offer, whether binding or non-binding, conditional or unconditional (including in regard to a proposed term sheet, memorandum of understanding, or letter of intent).

For the avoidance of doubt, action taken solely in order to obtain applicable information regarding an Opportunity or an Applicable Third Party's proposed terms and conditions pertinent to an Opportunity (including the purchase of a "bid package" from an applicable Government or entering into an applicable confidentiality agreement) shall not constitute an Offer/Acceptance.

Up-Front AMIAs generally provide (or at least should provide) for a procedure, sometimes similar to the procedure described in the AIPN Model SBA, ${ }^{19}$ according to which the Commercial Terms and the Other Material Provisions to be included in an Offer/Acceptance are determined. The procedure might begin with the meeting described in the Invitation to Participate, and include various steps occurring on prescribed dates subsequent to the date of the Invitation to Participate. Some Up-Front AMIAs provide that no party has any obligation to disclose: (1) applicable data in possession of such party; or (2) a party's own internal analyses (including fiscal, contractual, legal, technical, or political risk analyses).

Similar to the AIPN Model SBA, an Up-Front AMIA may provide that any party that elects not to participate in an Offer/Acceptance determined in accordance with the Up-Front AMIA shall be, for a stipulated period, prohibited from itself initiating the procedure (by way of issuing an Invitation to Participate) in regard to an Opportunity for which the procedure has already been initiated. 


\title{
K. How Disputes OVER COMMERCiAl Terms AND Other Material Provisions are Resolved
}

Similar to the AIPN Model SBA, an Up-Front AMIA might provide for each party electing to attend the meeting subsequent to the transmission of the Invitation to Participate to make its submissions regarding Commercial Terms and Other Material Provisions. These terms, respectively, might be defined as:

\begin{abstract}
Commercial Terms means commercial terms, as may be applicable, to be included in an Offer/Acceptance, including any applicable: (i) cash consideration (signature bonus) or work program commitments, including seismic and wells; and (ii) fiscal terms, including: milestone payments or bonuses; production sharing terms (including cost petroleum limits and profit petroleum splits, along with any associated sliding scales based upon production, an "R factor", or ROR); government participation percentage; royalties; profit taxes; additional profit taxes and other similar terms.
\end{abstract}

Other Material Provisions means the material terms, excluding Commercial Terms, to be included in an Offer/Acceptance, such as: contract term; provision of security; transfers of interest; termination; force majeure; repatriation of proceeds; stabilization; governing law; or dispute resolution provisions.

Consistent with the AIPN Model SBA, ${ }^{20}$ an Up-Front AMIA might provide that if the parties that wish to participate in an Offer/Acceptance in regard to an Opportunity cannot unanimously agree upon the set of Commercial Terms to be included in the Offer/ Acceptance, then the set of Commercial Terms proposed by any party that would be most competitive (from the perspective of the Applicable Third Party) shall be included in the Offer/Acceptance. ${ }^{21}$

An alternative approach (not provided for in the AIPN Model SBA), however, would be to provide for the applicable parties to first determine the "fiscal terms." 22 In the event of any failure of the parties to unanimously agree upon the set of "fiscal terms" to be included in the Offer/Acceptance, the set of "fiscal terms" proposed by any party that would be most competitive (from the perspective of the Applicable Third Party) shall be included in the Offer/Acceptance (an alternative would be to provide that the set of proposed "fiscal terms" garnering the highest "participating interest" vote shall be included in the Offer/Acceptance).

Then, in the event of any failure of the parties agreeing to go forward on the basis of such "fiscal terms" (determined as provided above) unanimously to agree upon the set of "cash consideration (signature bonus) or work program commitments" element of the Commercial Terms $^{23}$ to be included in the Offer/Acceptance - then the set of "cash consideration (signature bonus) or work program commitments" proposed by any such party that would be most competitive (from the perspective of the Applicable Third Party) shall be included

$20 \quad$ Ibid, art 6.1.

21 Please note that, as in the case of article 6 of the AIPN Model SBA, ibid, Up-Front AMIAs generally provide for each party to essentially have equal rights (pro rata in accordance with its "participating interest") in regard to each Opportunity that might arise within the AMI. The party initiating any attempt to exploit an Opportunity does not, for example, have the right to dictate what shall be provided to the Applicable Third Party by way of an Offer/Acceptance.

22 See the "fiscal terms" element in "(ii)" of the definition of "Commercial Terms," above.

23 Ibid. See the "cash consideration (signature bonus) or work program commitments" element in "(i)" of the definition of "Commercial Terms," above. 
in the Offer/Acceptance (an alternative would be to provide that the set of proposed "cash consideration (signature bonus) or work program commitments" garnering the highest "participating interest" vote shall be included in the Offer/Acceptance).

With respect to Other Material Provisions, the AIPN Model SBA is silent in regard to what happens in the event that unanimous agreement upon an Other Material Provision cannot be obtained by the applicable parties. That deficiency may, however, be rectified by providing that if the parties agreeing to the Commercial Terms (determined as provided above) cannot unanimously agree at the meeting upon the Other Material Provisions to be included in the Offer/Acceptance, then the set of Other Material Provisions proposed by any such party that is most competitive (from the perspective of the Applicable Third Party) ${ }^{24}$ shall be included in the Offer/Acceptance (an alternative would be to provide that the set of proposed Other Material Provisions garnering the highest "participating interest" vote shall be included in the Offer/Acceptance).

Any dispute over Commercial Terms, or Other Material Provisions, may be resolved by expert determination.

Only the parties that agree to participate in an applicable Offer/Acceptance on the basis of the Commercial Terms and Other Material Provisions determined in accordance with the Agreement shall be obligated to participate in the Offer/Acceptance as "Participating Parties."

Up-Front AMIAs also generally provide that the Participating Parties may not propose to an Applicable Third Party, as part of an Offer/Acceptance, Commercial Terms "reduced" to the equivalent of, or less than, Commercial Terms proposed by any non-Participating Party before first inviting such non-Participating Party to participate on the basis of the new Offer/Acceptance. Articles 6.7 and 6.7.1 of the AIPN Model SBA describe any such "reduction" in terms of "monetary value" (of the entirety of the Commercial Terms). ${ }^{25}$ This is, however, inconsistent with the "most competitive Commercial Terms" criterion described in article 6.1 (and article 7.1), and essentially makes no sense. ${ }^{26}$ This is because, for example, "Commercial Terms" is defined in the AIPN Model SBA to include both "minimum work" and "fiscal" terms. There is no generally accepted method to attach a "monetary value" to "fiscal terms" in the same way that a "monetary value" may be attached to "minimum work" (and no such method is provided for in the AIPN Model SBA). Accordingly, an Up-Front AMIA would better address this issue by way of applying the "most competitive" criterion on a consistent basis in regard to the Commercial Terms.

Also, the AIPN Model SBA is silent on the counterpart issue pertinent to Other Material Provisions. ${ }^{27}$ This deficiency may be rectified in a similar fashion, by providing that the agreed to by all of the applicable parties, then if one of the applicable parties had proposed that no stabilization provision be included among the Other Material Provisions to be included in the applicable Offer/Acceptance then that proposal would constitute the proposal that would be the most competitive (from the perspective of the Applicable Third Party).

Supra note 11 .

Ibid.

Ibid. 
Participating Parties may not propose to an Applicable Third Party, as part of an Offer/Acceptance, an Other Material Provision that is the equivalent of, or less competitive than, an Other Material Provision proposed by any non-Participating Party that otherwise had agreed with an Offer/Acceptance, before first inviting such non-Participating Party to participate on the basis of the new Offer/Acceptance.

\section{Parties Electing Not to Proceed With an Offer/Acceptance ARE Prohibited From MAKING an OfFer/ACCEPTANCE FOR A Stipulated Period of Time}

Similar to the AIPN Model SBA articles 12.1 and 12.2, Up-Front AMIAs generally provide that any party not agreeing to participate in an applicable Offer/Acceptance shall be prohibited from participating in the transmission of any competing Offer/Acceptance in regard to the applicable Opportunity for a stipulated period. ${ }^{28}$ One approach would provide for such stipulated period to end on the earliest of either: (1) the date occurring ___ days after the date of the applicable Invitation to Participate if such Offer/Acceptance has not been transmitted as of such date; or (2) the date occurring days after the date of the applicable Invitation to Participate - and in either such case then only in accordance with the procedures described in the Up-Front AMIA (with such party beginning the applicable procedure all over again by way of issuing an Invitation to Participate).

\section{OFFER/ACCEPTANCE COORDINATOR}

Most Up-Front AMIAs provide for one of the parties to coordinate the negotiations with the Applicable Third Party. The following describes one approach to this. Unless otherwise agreed to by the parties that elect to participate in an attempt to exploit an Opportunity on the basis of an Offer/Acceptance determined in accordance with the Up-Front AMIA (Participating Parties), only the Participating Party with the highest Participating Interest (Offer/Acceptance Coordinator) shall communicate an Offer/Acceptance, on behalf of the Participating Parties, to the Applicable Third Party, and shall copy all other Participating Parties on all correspondence with the Applicable Third Party. In the event that multiple Participating Parties each has a highest Participating Interest, then the Participating Parties shall determine the Offer/Acceptance Coordinator by way of a majority vote of the Participating Parties, each having a vote pro-rata in accordance with its respective Participating Interest. In the event of a tie vote, the Offer/Acceptance Coordinator shall be the Party that appears first in an order described in the Up-Front AMIA.

\section{N. Negotiation Costs}

Each party participating in an Offer/Acceptance (Participating Party) shall bear its pro rata share of any negotiation costs reasonably incurred by the Offer/Acceptance Coordinator. Otherwise, each party shall bear its own negotiation costs. 


\section{O. No Joint Study Provisions}

An Up-Front AMIA may or may not provide for joint study provisions (where applicable study operations are conducted by an operator, with the applicable costs being shared on a joint basis).

In any event, in circumstances such as in the case of an Opportunity that is the subject of a host government bid round, the associated oil companies could employ joint study provisions based upon the applicable AIPN Model SBA provisions. ${ }^{29}$

\section{P. Joint Operating AgreEment}

In any case where two or more Parties, by way of operation of an Up-Front AMIA, obtain an interest in a GPC associated with an Opportunity for which there was either no preexisting JOA or for which no JOA was negotiated with the Applicable Third Party by way of operation of the Up-Front AMIA, ${ }^{30}$ it will be necessary for such parties to employ a JOA. An Up-Front AMIA JOA may provide that such a JOA shall be the subject of two alternative provisions:

\section{ALTERNATIVE 1}

The Participating Parties shall, within (__ Days after an applicable transaction with an Applicable Third Party becomes effective in regard to an Opportunity, execute the Joint Operating Agreement attached as Exhibit [ ].

\section{ALTERNATIVE 2}

The Participating Parties shall, within (__ Days after an applicable transaction with an Applicable Third Party becomes effective in regard to an Opportunity, negotiate a Joint Operating Agreement on the basis of the operating principles set out in Exhibit [ ]. Until such Joint Operating Agreement is executed such operating principles shall govern the relationship of the participating Parties.

An Up-Front AMIA might also provide, in connection with the designation of the party who will serve as operator of the JOA:

In regard to any such JOA, shall be the Operator if it will have at least a Participating Interest in regard to the applicable Opportunity. Otherwise, shall be the Operator if it will have at least a Participating Interest

in regard to the applicable Opportunity. In all other cases then the Operator shall be selected by way of a majority vote of the applicable Participating Parties, each having a vote pro-rata in accordance with its respective Participating Interest. In the event of a tie vote, then the Offer/Acceptance Coordinator shall be the party that appears first in the order described in Article [ ].

29 Ibid.

30 Such as in the case of an applicable GPC with a host government. 


\section{Q. REMEDIES FOR BREACH OF OBLIGATION to Provide Invitation to Participate}

An Up-Front AMIA may provide for the remedies described below to apply in the event that: (1) a party fails to provide to another party the required Invitation to Participate prior to such party transmitting an Offer/Acceptance to an Applicable Third Party; and (2) such Party obtains an interest in a GPC associated with an Opportunity as a result.

A non-breaching party must make a claim of breaching party within one year of the time that the non-breaching party knows, or should have known, of breaching party's breach. ${ }^{31}$

At the option of the non-breaching party, the breaching party shall make a reasonable effort to attempt to obtain any applicable consents that would permit such breaching party to provide each non-breaching party with a description of the Opportunity reasonably adequate to permit each non-breaching party to make an informed decision whether or not to participate in the Opportunity. The breaching party shall not, however, have any obligation to disclose the breaching party's own internal analyses (including fiscal, contractual, legal, technical, or political risk analyses). If applicable, and again at the option of each nonbreaching party, breaching party shall make a reasonable effort to attempt to obtain any applicable consents or waivers that would permit such breaching party to transfer to each non-breaching party its pro rata share, based upon its participating interest, in the GPC (and any associated JOA) associated with the applicable Opportunity. ${ }^{32}$

It is recognized that it might be difficult for a non-breaching party to prove-up applicable damages associated with a party's breach of its obligation to provide an Invitation to Participate to each other party. Accordingly, what are essentially liquidated damages (assuming that that the values in (A) to (C) below would be less than 100 percent) might be provided for as described below.

If the effort to transfer an interest in the GPC (and any associated JOA) to a non-breaching party is successful, then such non-breaching party would have the obligation to reimburse the breaching party, free of interest, the following amounts:

(A) _ _ percent of the non-breaching party's pro rata share, based upon its participating interest, of any amount of consideration incurred by the breaching party;

(B) _ percent of the non-breaching party's pro rata share, based upon its participating interest, of any amount incurred by the breaching party either: (i) under any applicable JOA involving one or more third parties; or, if there is no such JOA, then (ii) on an arm's length basis; and

Of course, a lesser or longer time period may be provided for.

These obligations would essentially constitute the applicable obligations of a party that has exploited an Opportunity under an After the Fact AMIA to each of the other parties. 
percent of the non-breaching party's pro rata share, based upon its Participating Interest, of any transactional cost incurred by the breaching party (such as legal fees paid by the breaching party for the original transfer of interest to the breaching party). ${ }^{33}$

The breaching party shall notify each non-breaching party of the applicable amounts that would be payable by each non-breaching party, and each applicable non-breaching party shall have 30 days to make such payment. Otherwise any such non-breaching party shall be deemed to have rejected the opportunity to participate with the breaching party. Nonbreaching parties shall have reasonable audit rights in regard to the applicable amounts.

As indicated above, oil companies may choose to employ percentages in relation to (A), (B), or (C), above, that are less than 100 percent. Although there is little case law on the subject, the general view appears to be that under common law, and under most civil code systems, liquidated damages must essentially approximate the actual damages in order to be enforceable - and that those liquidated damages that are perceived to be in excess of the actual damages may be viewed as a "penalty" and, accordingly, as an unenforceable contract provision. It is difficult to know how low the percentages in relation to $(A),(B)$, or $(C)$, above, might be before, in any given legal jurisdiction, they would be characterized as a penalty and therefore unenforceable. ${ }^{34}$

At the same time, it is recognized that breach of an Up-Front AMIA by a party, unlike the case of a party to a JOA defaulting on a cash call or other payment obligation, essentially results in the wrongful appropriation by such party of an Opportunity that each other party to the Up-Front AMIA should itself have had the right to attempt to exploit in the first place. In this way, equitable principles such as "constructive trust" and "unjust enrichment" come to mind. The objective of the remedy described above would be essentially to provide the non-breaching party with the benefit of its bargain to the extent possible in the circumstances; and, at the same time, essentially "penalize" the breaching party to a degree that would not be unenforceable. Without some degree of "penalty" the remedy would provide essentially no incentive for a party not to breach the Up-Front AMIA. In such a case, an applicable Up-Front AMIA would essentially be converted into an After the Fact AMIA - but with each non-breaching party essentially being deprived of the rights that it was expecting to have (such as the right to attempt to exploit the Opportunity, including the attempt to obtain required consents or applicable waivers, "shoulder to shoulder" with the breaching party; along with the right to participate in the determination of the applicable Maximum Commercial Terms and Minimum Material Provisions that would be included in each applicable Offer/Acceptance). ${ }^{35}$

These obligations are essentially analogous to the applicable obligations of the applicable parties of an After the Fact AMIA (who chose to participate in an Opportunity) to a party that has exploited an Opportunity, but on the basis that the values in (A)-(C) above would be 100 percent.

34 AIPN Model SBA, supra note 11, art 12. Article 12.1 of the AIPN Model SBA provides that if a party breaches the AIPN Model SBA by way of entering into a GPC outside of the procedures prescribed by the AIPN Model SBA, then such party shall transfer to the non-breaching party's 100 percent of the interest in the breaching party in such GPC. Such remedy might not be enforceable in some legal jurisdictions.

35 In view of the many terms and conditions that would normally be expected to reside in a sale and purchase agreement (SPA) that would be applicable to such a contemplated transaction between a breaching party and a non-breaching party, IOCs may wish to attach an example form SPA to the UpFront AMIA. 
An Up-Front AMIA may or may not provide that if the breaching party is unable, after making reasonable efforts, to obtain either: (1) all applicable consents that would permit the breaching party either to provide to each non-breaching party a description of the Opportunity reasonably adequate to permit each non-breaching party to make an informed decision whether or not to participate in the Opportunity; or (2) all applicable consents or waivers that would permit a breaching party to transfer to such non-breaching party its pro rata share, based upon its participating interest, in the GPC (and any associated JOA); then, at the non-breaching party's option, the breaching party shall have the obligation to pay the non-breaching party, within 30 days of the non-breaching party's notice, percent what would have been, but for the breach by the breaching party, the fair market value (FMV), as of the date of such non-breaching party's claim against the breaching party, of such non-breaching party's interest in the GPC (and any associated JOA), free of interest, less the following amounts:

percent of what would have been the non-breaching party's pro rata share, based upon its participating interest, of any amount of consideration incurred by the breaching party;

(B) _ percent of what would have been the non-breaching party's pro rata share, based upon its participating interest, of any amount incurred by the breaching party either: (i) under any applicable JOA involving one or more third parties; or, if there is no such JOA, then (ii) on an arm's length basis; and

(C) _ percent of what would have been the non-breaching party's pro rata share, based upon its participating interest, of any transactional cost incurred by the breaching party (such as legal fees paid by the breaching party for the original transfer of interest to the breaching party).

If applicable parties cannot agree upon the FMV, then expert determination would be applicable, analogous to article 12.3 of the AIPN Model Form International Joint Operating Agreement, pertaining to expert determination of "Cash Value" in context of "Change in Control." 36

The non-breaching party shall have reasonable audit rights in regard to the applicable amounts.

The considerations described above in regard to the enforceability of liquidated damage provisions should also be applied to the above.

In any event, oil companies might consider, in the context of the determination of how to choose the applicable discount to what would have been, but for the breach by the breaching party, the FMV of the non-breaching party's interest in the GPC (and any associated JOA), that the chosen discount might reflect the possibility that applicable consents or waivers 
could not have been obtained even in a case where there was no breach by the breaching party in the first place.

It is also recognized that, particularly in a case where there have been significant operations undertaken subsequent to the breaching party's breach (resulting in significant costs incurred by the breaching party), such operations may have significantly increased the FMV of what would have been the non-breaching party's interest in the GPC vis-à-vis the applicable FMV at the time of the breaching party's breach.

Additionally, it is recognized that, in the same way that there is no security provided for under JOAs (and often the special purpose legal entities signing JOAs are undercapitalized), without the provision of security any obligation of the breaching party to pay a nonbreaching party the stipulated damages might be difficult to enforce. ${ }^{37}$

\section{R. Optional Provision Providing for Good Faith Duty}

It might be difficult for any such non-breaching party to verify whether or not the breaching party had indeed made reasonable efforts to obtain any necessary consents or waivers as may be required either to disclose applicable information to each non-breaching party or to transfer an applicable interest to a non-breaching party. Oil companies may wish to consider whether or not to provide that the breaching party shall perform such applicable obligations in good faith (or to provide for a generalized duty of good faith). ${ }^{38}$

\section{S. Affiliate Compliance}

Up-Front AMIAs often provide that each party shall procure that each of its affiliates shall comply with the Up-Front AMIA as though each such affiliate were a party to the Up-Front AMIA.

Because it is recognized that a party may not necessarily be able to procure its affiliate's compliance with the Up-Front AMIA, however, oil companies may wish to provide for each party to provide an ultimate parent guarantee that the Up-Front AMIA will be adhered to.

\section{T. WARRANTIES REgarding Similar AgreEMENTS}

Consideration may also be given to providing for each party to warrant that, in regard to the AMI, neither it nor any of its affiliates is a party to a pre-existing AMIA (including an SBA, TEA, or similar agreement) that provides for such party to have obligations to any third party that are similar to the obligations described in the Up-Front AMIA, except in connection with any rights provided for under a pre-existing GPC or JOA that pertain to a 
right of first refusal, right of first negotiation, or change in control provision in connection with a participating interest under such GPC or JOA. ${ }^{39}$

Similarly, consideration may also be given to providing for each party to warrant that, in regard to the AMI, neither it nor any of its affiliates shall enter into any AMIA (including an SBA, TEA, or similar agreement) that provides for such party to have obligations to any third party that are similar to the obligations described in the Up-Front AMIA, excepting in connection with any rights provided for under a pre-existing GPC or JOA that pertain to a right of first refusal, right of first negotiation, or change in control provision in connection with a participating interest under such GPC or JOA — unless such AMIA were made expressly subject to the Up-Front AMIA.

\section{U. EXCLUSION OF CORPORATE ACQUiSitions}

Oil companies may also wish to include a provision that excludes from the application of the Up-Front AMIA any Opportunity located within the AMI that would be the subject of a corporate acquisition, by way of a prospective share acquisition (or similar ownership acquisition) which would result in an applicable entity becoming an affiliate of a party.

Alternatively, consideration might be given to excluding from the application of the UpFront AMIA any Opportunity located within the AMI that would be the subject of a corporate acquisition, by way of a prospective share acquisition (or similar ownership acquisition) which would result in an applicable entity becoming an affiliate of a party, where the value of the Opportunity represents less than percent of the aggregate value of the entity being acquired. Any dispute regarding whether the value of an Opportunity represents less than percent of the aggregate value of the applicable entity being acquired may be resolved by way of expert determination. In any case where the value of the Opportunity represents an amount equal to or greater than percent of the aggregate value of the entity being acquired, then each other party shall have the right to participate in any Offer/Acceptance regarding the prospective acquisition of the Opportunity, with the "Cash Value" of such Opportunity determined analogously with the determination of the applicable "Cash Value" that is the subject of article 12.3 of the of the AIPN Model JOA. ${ }^{40}$

\section{Canadian Competition Law Considerations}

\section{A. INTRODUCTION}

Part II of this article draws an important distinction between a Non-Compete AMIA on the one hand, and Up-Front AMIAs and After the Fact AMIAs, on the other. Canadian competition law prohibits anticompetitive behaviour in the form of collaboration among competitors that restrains competition. As such, it is a general rule of Canadian commercial

39 A party, or one of its affiliates, may have, prior to the effective date of the Up-Front AMIA, entered into an applicable AMIA that involved one or more third parties that provide for obligations similar to the obligations provided for in this Agreement. If so, then the right to attempt to exploit an applicable Opportunity that a party would otherwise be entitled to would be diminished. In any event, any such party could simply refrain from agreeing to include the contract area of any such pre-existing AMIA in the AMI pertinent to the Up-Front AMIA. Supra note 36. 
law that market participants who are competitors cannot agree not to compete with one another.

Non-Compete AMIAs essentially prohibit a party from itself attempting to exploit an Opportunity without the consent of at least one other party. In our view, a Non-Compete AMIA would be legally characterized as producing a restraint on competition and would likely be determined to be per se illegal under the Competition Act as it would manifest an agreement by at least one party not to compete with at least one of the other parties. This creates potential exposure to civil sanctions — but would likely not attract criminal sanctions.

In the case of an Up-Front AMIA, a party does not agree not to compete with the other parties. To the contrary, under an Up-Front AMIA, each party is granted the right to join in any attempt by any other party to exploit an Opportunity within the AMI. Such right is subject only to such party's obligation to provide each other party with the option to participate in any attempt made by such party.

Whether or not an Up-Front AMIA might be legally characterized as producing a restraint on competition — and, as a result, be per se illegal — might depend upon what sort of mechanism is employed to address a dispute over what terms and conditions would be proposed, by way of an applicable offer or acceptance, to an Applicable Third Party. If such a mechanism were that the most competitive terms and conditions proposed by any party shall constitute the terms and conditions that will be proposed to the Applicable Third Party, then it would appear to be likely that the associated Up-Front AMIA would not be legally characterized as producing a restraint on competition - and, as a result, would not be determined to be per se illegal. If, however, such a mechanism were that the terms and conditions proposed by any party that obtains the highest vote from among the parties wishing to participate in the attempted exploitation shall constitute the terms and conditions that will be proposed to the Applicable Third Party, then there would appear to be a greater likelihood that the associated Up-Front AMIA would be legally characterized as producing a restraint on competition - and, as a result, would be determined to be per se illegal.

In the case of an After the Fact AMIA, each party may itself attempt to exploit an Opportunity without even first notifying each other party. For this reason it is difficult to see how an Up-Front AMI would be legally characterized as producing a restraint on competition - and, as a result, would likely not be per se illegal.

In any event, even in the case of a per se illegal Non-Compete AMIA (or any AMIA determined to be per se illegal), as long as it provided for potential collaboration on attempts to exploit Opportunities within the AMI going forward (even on the basis that each party would have no right to itself attempt to exploit an opportunity without the consent of at least one other party), then such Non-Compete AMI (or other AMIA) would likely be legally permissible under Canadian competition law. 


\section{B. OVERVIEW OF CANAdian COMPETITION LAW}

Canadian competition law is primarily statute-driven. The Competition Act traces its existence to $1889^{41}$ and predates its American counterpart, the Sherman Antitrust Act, ${ }^{42}$ by one year. During this time, the Competition Act has seen significant expansion, most notably by way of a comprehensive amendment enacted in March 2009. By contrast, antitrust law in the United States has been developed primarily through jurisprudence in the American courts. Given the paucity of Canadian jurisprudence applying the Competition Act in the context of oil and gas exploration and production activities, and given that an AMIA has not yet been the subject of Competition Act review at the time of this writing, Canadian competition law considerations discussed herein have been analyzed primarily on the basis of the text of the Competition Act, along with the applicable guidance made available by the Competition Bureau of Canada. ${ }^{43}$

The goal of competition law is to promote a competitive Canadian marketplace while protecting the broader public interest, through the regulation of unfair business practices. ${ }^{44}$ The Competition Act applies to all businesses and business activities in Canada ${ }^{45}$ and concerns three main areas of business conduct that may be harmful to competition: (1) coordinated conduct among competitors; (2) abuse of dominance; and (3) mergers. ${ }^{46}$ Our opinion is that conceptually, an AMIA is most likely captured by this first branch of Canadian competition law.

The Competition Act is enforced by the Competition Bureau of Canada (the Bureau). The Bureau is led by the Commissioner for Competition (the Commissioner). If the Commissioner suspects a criminal breach of the Competition Act, the Commissioner can conduct a formal inquiry, in collaboration with the Director for Public Prosecutions. ${ }^{47}$ Inquiries can also be petitioned by groups of six or more persons. ${ }^{48}$ The Commissioner can also initiate administrative proceedings before the Competition Tribunal with respect to civil matters, including anticompetitive agreements. Criminal offences under the Competition Act are prosecuted by the Director of Public Prosecutions and can be brought before the superior courts in each province or the Federal Court, as applicable.

Halsbury's Laws of Canada, Competition and Foreign Investment (Markham, Ont: LexisNexis Canada, 2014) at HCT-34 "Evolution of the Statute" [Halsbury's].

15 USC $\$ \S 1-7$ (1890) [Sherman Act].

Competition Bureau Canada, "Competitor Collaboration Guidelines," Enforcement Guidelines (Ottawa: Competition Bureau, 23 December 2009), online: <www.competitionbureau.gc.ca/eic/site/cb-bc.nsf/ eng/03177.html > ["Guidelines"].

Halsbury's, supra note 41 at HCT-33.

Of note, section 465(3) of the Criminal Code, RSC 1985, c C-46, provides that persons who conduct an illegal conspiracy in a place outside Canada that is an offence under the laws of that place shall be deemed to have conspired to do that thing in Canada. This is commonly understood to give potential extra-territorial scope to the Competition Act, supra note 2, however this point is beyond the scope of this article. Canadian companies using an AMIA abroad should be cognizant of this potential extraterritorial application of the Competition Act.

"Guidelines," supra note 43 at 3-4.

Ibid, s 10

Ibid, s 9. 


\section{Section 45: Conspiracies, Agreements, OR ARrangements Between COMPETITORS}

Section 45 of the Competition Act creates a per se criminal offence for conspiracies or agreements or arrangements between competitors. Section 45 is one of two "tracks" by which a conspiracy claim might proceed, being the "criminal track," in contrast to the "civil track" existing under section 90.1, which is further discussed below. The conspiracy offence under section 45 carries with it a sanction, on conviction, of imprisonment for a term not exceeding 14 years or a fine not exceeding \$25 million, or both. ${ }^{49}$ The standard of proof that the prosecution must meet in order to prove the offence is proof beyond a reasonable doubt. ${ }^{50}$ As a threshold matter, the Bureau will determine on the basis of the available evidence whether to proceed on the section 45 criminal track or section 90.1 civil track, with the serious criminal sanction of the former "reserved for agreements between competitors to fix prices, allocate markets or restrict output that constitute 'naked restraints' on competition (restraints that are not implemented in furtherance of a legitimate collaboration, strategic alliance or joint venture). ${ }^{, 51}$ Conversely, other forms of competitor collaboration, including joint ventures and strategic alliances, are subject to less stringent review and fall under civil review provisions where such agreements are likely to lessen or prevent competition. ${ }^{52}$

On this basis, we would expect that if the Bureau were to review a Non-Compete AMIA, Up-Front AMIA, or After the Fact AMIA, they would most likely proceed down the civil track. However, there is relevant Canadian case law precedent for a competitor agreement in the oil and gas industry proceeding down the criminal track and we will therefore also consider its applicability. ${ }^{53}$ The relevant provisions of section 45 of the Competition Act are as follows:

Conspiracies, agreements or arrangements between competitors

45(1) Every person commits an offence who, with a competitor of that person with respect to a product, conspires, agrees or arranges

(a) to fix, maintain, increase or control the price for the supply of the product;

(b) to allocate sales, territories, customers or markets for the production or supply of the product; or

(c) to fix, maintain, control, prevent, lessen or eliminate the production or supply of the product. ${ }^{54}$

While it is not immediately apparent from the wording of section 45 how it might apply to an AMIA, unpacking the definitions of the various terms described above proves enlightening. Firstly, the definition of "competitor" includes "a person who it is reasonable

Ibid, s 45(2).

Ibid, s 45(3).

"Guidelines," supra note 43 at 3 [footnote omitted]. This same threshold consideration applies to the criminal sanction for bid-rigging contained in section 47. Agreements to form bidding consortia or similar arrangements that do not meet the level of criminality can be reviewed under section 90.1

Ibid.

321665 Alberta Ltd v ExxonMobil Canada Ltd et al, 2013 ABCA 221, 533 AR 295, leave to appeal to SCC refused, 35529 (16 January 2014) [ExxonMobil CA].

Competition Act, supra note 2, s 45(1). 
to believe would be likely to compete with respect to a product in the absence of a conspiracy, agreement or arrangement to do anything referred to in paragraphs (1)(a) to (c). ${ }^{55}$ This definition has been interpreted to include potential competitors. ${ }^{56}$ Two different exploration and production companies that could potentially conduct operations within an AMI area are certainly "competitors" in respect of the Competition Act.

Secondly, "product" is defined as including "an article and a service." "57 "[S] ervice" means "a service of any description whether industrial, trade, professional or otherwise," "article":

means real and personal property of every description including:

(a) money,

(b) deeds and instruments relating to or evidencing the title or right to property or an interest, immediate, contingent or otherwise, in a corporation or in any assets of a corporation,

(c) deeds and instruments giving a right to recover or receive property

... and

(e) energy, however generated. ${ }^{59}$

These definitions are clearly intended to be as broad and inclusive as possible and certainly capture all aspects of business operations, including oil and gas exploration and production activity. As a result, an AMIA could certainly be interpreted, in the context of sections 45(1)(b) and (c) of the Competition Act, to be an agreement: 45(1)(b) to allocate sales, territories, customers, or markets for the production or supply of a product; or (c) to fix, maintain, control, prevent, lessen, or eliminate the production or supply of the product.

Competitor agreements that restrain competition are per se prohibited under section 45 of the Competition Act as being a competitor agreement which restricts competition. Critically, however, section 45 contains the following "ancillary restraints defence":

Defence

(4) No person shall be convicted of an offence under subsection (1) in respect of a conspiracy, agreement or arrangement that would otherwise contravene that subsection if

(a) that person establishes, on a balance of probabilities, that

Ibid, s 45(8).

"Guidelines," supra note 43 at 7.

Competition Act, supra note 2, s 2(1).

Ibid.

Ibid. 
(i) it is ancillary to a broader or separate agreement or arrangement that includes the same parties, and

(ii) it is directly related to, and reasonably necessary for giving effect to, the objective of that broader or separate agreement or arrangement; and

(b) the broader or separate agreement or arrangement, considered alone, does not contravene that subsection. ${ }^{60}$

The "ancillary restraints defence" is available when:

(a) The restraint is ancillary to a broader or separate agreement that includes the same parties;

(b) The restraint is directly related to, and reasonably necessary for giving effect to, the objective of the broader or separate agreement referred to in (a) above; and

(c) The broader or separate agreement referred to in (a) above, when considered in the absence of the restraint, does not contravene subsection $45(1){ }^{61}$

Applied to a Non-Compete AMIA, the "restraint" on competition would flow from the noncompete provision therein. The "broader ... agreement" which would give rise to a party's successful ancillary restraints defence would be the remainder of the terms of the NonCompete AMIA which provide for potential collaboration among the parties on attempts to exploit Opportunities within the AMI going forward (even on the basis that each party would have no right to itself attempt to exploit an Opportunity without the joint participation of at least one other party or the consent of all other parties). This also applies in the case of an Up-Front AMIA or an After the Fact AMIA; however, we do not believe such AMIAs to be per se illegal and therefore no defence should be required.

Additionally, the Bureau has provided guidance as to what forms of competitor agreements may qualify for the section 45(4) "ancillary restraints defence." With respect to section 45(4)(a)(i) of the defence, the Bureau states that "ancillary" means that "the restraint is a part of an agreement or is a separate agreement." ${ }^{62}$ It appears that any AMIA, including one that provides for a party to agree not to compete with one or more other parties (such as in the case of a Non-Compete AMIA), is defensible if it is part of a broader legitimate commercial relationship; that is, if it provides for potential collaboration on attempts to exploit Opportunities within the AMI going forward.

The Bureau gives an example of the applicability of the "ancillary restraints defense," citing a hypothetical non-compete agreement being entered into in contemplation of a broader joint venture agreement. ${ }^{63}$ We would argue that this statutory defence is broadly

"Guidelines," supra note 43 at 13.

Ibid.

Ibid. 
similar to the approach adopted by the United States Department of Justice (DOJ) in the US SGI Interests case discussed below. ${ }^{64}$

We would, in any event, caution that any analysis of an AMIA by the Bureau or a court would almost certainly turn on the substance, not the categorization, of such an agreement. If the terms of an impugned agreement represented a naked restraint on competition we would expect this to attract criminal liability, regardless of whether the parties called it an AMIA or otherwise.

While not pertinent to an AMIA and therefore distinguishable on its facts, the recent Alberta Court of Appeal case ExxonMobil ${ }^{65}$ considered the application of section 45 to joint operations in the oil and gas industry generally. In that case, Husky Oil Operations Ltd. (Husky) and ExxonMobil Canada Ltd. (ExxonMobil) both operated oil and gas properties in the Rainbow Lake area of Alberta. Each had solely owned properties and were joint owners on certain other properties, which Husky operated. Husky and ExxonMobil decided that it would be advantageous to form "a bi-company team to investigate ways to more effectively 'partner' in the Rainbow Lake area." ${ }^{\prime 66}$ The intent of this partnership was to operate all properties in the area as if they were "one operation rather than separated." ${ }^{167}$ One area of opportunity identified by the parties was an efficiency gain through lower operating costs. On this basis, the parties decided to use a single contractor to provide certain oilfield services, rather than to continue relying on two different contractors. The plaintiff (Kolt) was one of the two contractors competing for business in the area and relied on Husky for over 50 percent of its revenues. It was not awarded the joint contract. At trial, the Alberta Court of Queen's Bench found Husky and ExxonMobil's conduct to be contrary to the section 45 criminal sanction for conspiracy and competitor agreement and awarded Kolt damages totalling its approximate profits for the subsequent 14.5 years plus CDN\$1 million in punitive damages. ${ }^{68}$

However, the Alberta Court of Appeal recognized that competitors entering into a joint purchasing agreement aimed at increasing operational efficiencies was not in violation of section 45 and reversed the trial judge's decision. The Alberta Court of Appeal recognized that cooperation through joint operations is an important part of the oil and gas industry. In its judgment, the Court found that "the oil and gas regime in Alberta anticipates and relies on cooperation between and amongst owners of properties" ${ }^{\prime 9}$ and in this case the parties had merely "collaborated with one another in a manner that is common for oil and gas development." ${ }^{70}$ The impugned agreement between Husky and ExxonMobil was found not to be anticompetitive and not contrary to the Competition Act.

What can be gleaned from this case is the fact that some form of competitor collaboration is necessary in the course of joint operations in the Canadian oilfield. As a result, legitimate

United States v SG Interests I, Ltd, 2013 WL 1932944 (D Colo 2013) [SGI Interests].

Supra note 53.

Ibid at para 3.

Ibid.

321665 Alberta Ltd v ExxonMobil Canada Ltd et al, 2012 ABQB 76, 529 AR 276.

ExxonMobil CA, supra note 53 at para 28.

Ibid at para 29 . 
competitor agreements aimed at increasing efficiency and decreasing operating costs will not attract criminal liability under section 45 .

\section{SECTION 90.1}

The second "track" applicable to competitor agreements is the civil remedy contained in section 90.1 of the Competition Act. ${ }^{71}$ This civil remedy is available for inquiries into anticompetitive behaviour that is not elevated to the level of serious criminality. As discussed above, we consider it most likely that a Non-Compete AMIA, Up-Front AMIA, or After the Fact AMIA would be examined under section 90.1, rather than section 45 or section 47 (if at all). The relevant provision of Section 90.1 is as follows:

Order

90.1 (1) If, on application by the Commissioner, the Tribunal finds that an agreement or arrangement whether existing or proposed — between persons two or more of whom are competitors prevents or lessens, or is likely to prevent or lessen, competition substantially in a market, the Tribunal may make an order

(a) prohibiting any person — whether or not a party to the agreement or arrangement - from doing anything under the agreement or arrangement; or

(b) requiring any person - whether or not a party to the agreement or arrangement — with the consent of that person and the Commissioner, to take any other action. ${ }^{72}$

Section 90.1 deals with civil competitor collaboration and is aimed at agreements that are not necessarily anticompetitive and are not per se criminal, but have the potential to adversely affect competition. While not attracting the severe penalties of fines and imprisonment contained in section 45 , section 90.1 does provide that the Tribunal may make an order prohibiting any person from "doing anything under the agreement or arrangement." $"$ Essentially, this represents an injunction preventing the competitors from implementing the impugned agreement. The section 90.1 civil track remedy allows the Commissioner to challenge any agreement or arrangement between competitors. The applicable test that the Commissioner will apply when imposing a remedial order is whether the agreement or arrangement is likely to prevent or "lessen competition substantially" in a market. $^{74}$ The Bureau has interpreted such agreements as those that are likely to create, maintain, or enhance the ability of the parties to the agreement to exercise market power, for example, by sustaining higher prices in a market than would have existed were competition to exist. ${ }^{75}$

There is an exception under section 90.1(4) that provides a complete defence where the agreement or arrangement has resulted in gains in efficiency that are greater, and will offset

Competition Act, supra note 2.

Ibid.

Ibid.

"Guidelines," supra note 43 at 20.

Ibid. 
the effects of preventing or lessening competition, and where such gains would not occur if the Tribunal order were to be made:

Exception where gains in efficiency

(4) The Tribunal shall not make an order under subsection (1) if it finds that the agreement or arrangement has brought about or is likely to bring about gains in efficiency that will be greater than, and will offset, the effects of any prevention or lessening of competition that will result or is likely to result from the agreement or arrangement, and that the gains in efficiency would not have been attained if the order had been made or would not likely be attained if the order were made. ${ }^{76}$

Such risk sharing and efficiency gains were key in the result of the SGI Interests case discussed below. ${ }^{77}$ In Canada, the Bureau allows that efficiency gains realized through competitor collaborations, such as cost reductions and operational infrastructure improvements, are desirable aims in business and will be considered against the anticompetitive effects that are likely to result from the agreement. ${ }^{78}$ Based on this guidance and the authority of the SGI Interests case, we view an AMIA as being permissible under Canadian competition law if it provides for potential collaboration on attempts to exploit Opportunities within the AMI going forward..$^{79}$ However, we would caution that in any review by the Bureau, the burden of proof would be placed on the parties to the AMIA to demonstrate that the efficiency gains, cost savings, and other benefits brought about by the AMIA would be greater than, and would offset, any anticompetitive effect. ${ }^{80}$

\section{E. SECTION 47: BID-RIGGING}

An additional criminal offence under section 47 of the Competition Act only applies to agreements entered into in relation to the submission of competitive bids, such as in response to a request for proposals or call for bids ${ }^{81}$ In the Canadian oil and gas industry, this would be most readily applicable to the grant of tenure in minerals by the Crown in right of the provinces in respect of which oil and gas exist. Each of British Columbia, Alberta, Saskatchewan, Nova Scotia, and Newfoundland and Labrador conduct a competitive bid process through which exploration and production companies receive their interest in Crown mineral rights. If companies enter into an AMIA that will result in bidding on Crown mineral rights, it is conceivable that the criminal offence section 47 could apply, if care is not taken in drafting the agreement. The relevant provision of section 47 reads as follows:

\section{Definition of bid-rigging}

47(1) In this section, bid-rigging means

(a) an agreement or arrangement between or among two or more persons whereby one or more of those persons agrees or undertakes not to submit a bid or tender in response to a call or request

Competition Act, supra note 2.

Supra note 64.

"Guidelines," supra note 43 at 22.

Supra note 64.

"Guidelines," supra note 43 at 22.

Competition Act, supra note 2. 
for bids or tenders, or agrees or undertakes to withdraw a bid or tender submitted in response to such a call or request, or

(b) the submission, in response to a call or request for bids or tenders, of bids or tenders that are arrived at by agreement or arrangement between or among two or more bidders or tenderers,

where the agreement or arrangement is not made known to the person calling for or requesting the bids or tenders at or before the time when any bid or tender is submitted or withdrawn, as the case may be, by any person who is a party to the agreement or arrangement. ${ }^{82}$

Like the previously discussed criminal conspiracy provisions of section 45 , section 47 carries with it sanctions, on conviction, of a fine in the discretion of the court or imprisonment for a term not exceeding 14 years, or both. ${ }^{83}$ It is also a per se criminal offence.

Under section 47(1), bid-rigging occurs where (a) an agreement exists between two or more persons and one or more of those persons agrees to refrain from submitting a bid or tender, or to withdraw a bid or tender in response to a call; or (b) where the submission of a bid or tender are arrived at by agreement between two or more bidders ${ }^{84}$ Bid-rigging will not occur where any person who is a party to the agreement discloses the existence of the agreement or arrangement to the person calling for the bids or tenders at or before the time the bid or tender is either submitted or withdrawn. ${ }^{85}$

In its "Guidelines," the Bureau states that there are acceptable instances where bidders may need to form a bid consortia to effectively bid for certain projects. ${ }^{86}$ It is further possible that the Bureau might proceed under both sections 45 and 47 if an agreement contains both criminal bid-rigging and other criminal anticompetitive elements. ${ }^{87}$ Further to the last paragraph of section 47(1), it is important that parties jointly entering into a competitive bid process inform the party requesting the bids or tenders of the existence of their agreement. ${ }^{88}$

Given the lack of Canadian jurisprudence on the subject, it is helpful to consider an illustrative case from the United States. By way of background, under the Sherman Act, much like under its Canadian counterpart, every agreement in restraint of trade or commerce among the states is per se illegal, and carries with it fines of USD \$100 million (for corporations) or USD $\$ 1$ million and imprisonment for a term of ten years (for individuals). ${ }^{89}$ However, such agreements may be permissible under the "rule of reason" analysis adopted by the US courts, when such agreements are reasonably necessary to achieve the procompetitive benefits expected from broader competitor collaborations. ${ }^{90}$

Ibid.

Ibid, s 47(2).

Ibid, s 47(1).

Ibid.

"Guidelines," supra note 43 at 2.

Ibid.

Competition Act, supra note 2.

Sherman Act, supra note 42, § 1 .

Jose P Puyana, "Joint Bidding and Antitrust Concerns in the Oil \& Gas Industry: Lessons from the SGI Interests Case"(2013) [unpublished, archived at Georgetown University Law Center] at 3 . Puyana notes that the US Supreme Court has a developed line of jurisprudence that distinguishes (1) those agreements considered per se illegal because of "their pernicious effects on competition and lack of any redeeming virtue" (see Northern Pacific Railway Company v United States, 78 S Ct 514 (1958); White Motor 
The SGI Interests case ${ }^{91}$ represents the first time the DOJ sought a criminal conviction in respect of anticompetitive joint bidding agreements entered into in order to acquire mineral leases. ${ }^{92}$ On 22 April 2013, the Colorado District Court authorized the DOJ's settlement with the defendants, with the result being that each company agreed to pay a fine of USD $\$ 275,000$ and notify the DOJ of any joint bidding at federal oil and gas lease auctions for a period of five years.

The factual background of SGI Interests involves competitor companies: SG Interests I, Ltd. and SG Interests VII, Ltd. (collectively SGI) and Gunnison Energy Corporation (GEC), who were interested in acquiring leases in the same part of the Ragged Mountain Area of Colorado, through a Bureau of Land Management (BLM) land auction. The parties entered into a memorandum of understanding (the MOU) pursuant to which only SGI would bid on the leases and then assign a 50 percent interest to GEC. Under the MOU, the parties acquired four joint mineral leases. Subsequently, the parties entered into an option and participation agreement (the OPA) and an AMIA (the SGI AMIA) which provided that the parties would jointly acquire additional BLM and private leases in the Ragged Mountain Area. Under the SGI AMIA, the parties acquired 18 additional leases. The DOJ determined that the MOU represented a per se violation of section 1 of the Sherman Act, as it intended to suppress bidding prices for the original four leases and it did not explicitly relate to a broader collaboration. However, because the SGI AMIA was "ancillary to the broader efficiency enhancing collaboration reflected in other provisions of the [SGI AMIA] and the simultaneously executed OPA," the joint bidding conducted thereunder was not illegal and the 18 remaining leases were legitimately acquired. ${ }^{93}$

In essence, the DOJ determined that the MOU represented a bid-rigging scheme to lower the price per acre that the BLM would have otherwise received for the lands by restricting competition. On the other hand, the SGI AMIA was not illegal based on the rule of reason analysis. The SGI AMIA represented permissible joint bidding that "contemplates subsequent joint productive activity, which entails a measure of risk sharing or joint provision of some good or service. ${ }^{.94}$ The existence of the SGI AMIA was permissible under US antitrust law because it was part of a wider aim to increase efficiencies among competitors by allowing the parties "to pool their resources and share the risks of exploration for, and development of, the natural resources. ${ }^{" 95}$ On the other hand, the MOU was a standalone document that merely limited competition and did not address the later collaboration. The DOJ stated that "the fact that Defendants ultimately established such a collaboration does not transform their prior agreement not to compete into a lawful ancillary restraint."

Company v United States, 83 S Ct 696 (1963); Continental TV, Inc v GTE Sylvania Incorporated, 97 $\mathrm{S} \mathrm{Ct} 2549$ (1977)); and (2) those agreements to be assessed under a rule of reason that takes into consideration the nature, purpose, and overall economic effect in the market (see National Society of Professional Engineers v United States, 98 S Ct 1355 (1978)).

SGI Interests, supra note 64.

Puyana, supra note 90 at 2.

SGI Interests, supra note 64 (Memorandum of the Plaintiff at 8), online: <https://www.justice.gov/atr/ case-document/file/510536/download>.

SGI Interests, ibid (Response of Plaintiff at 15), online: <https://www.justice.gov/atr/case-document/ file/510586/download $>$ [citation omitted].

Ibid at 8 .

Ibid. 
SGI Interests provided the DOJ with an opportunity to clarify its stance on joint operations in the oil and gas industry, and may be illustrative of the potential future approach of the Canadian Competition Bureau. The rule that emerged in the US is that whether or not a provision in an AMIA restricting a party's ability to attempt to exploit an Opportunity is per se illegal, or, instead, permissible under a rule of reason, depends on whether or not the AMIA also provides for potential collaboration on attempts to exploit Opportunities within the AMI going forward which may result in prospective joint ventures in regard to which risk sharing and efficiency gains by way of sharing of resources may be realized.

\section{F. CONCLUSIONS}

Based on the foregoing, oil companies should take care when negotiating an AMIA for use in Canada. A Non-Compete AMIA would likely be characterized as producing a restraint on competition and could be determined to be per se illegal - creating potential exposure to civil sanctions - but would likely not attract criminal sanctions. In contrast, it would be less likely for an Up-Front AMIA, or an After the Fact AMIA, to be legally characterized as producing a restraint on competition and be determined per se illegal. This is because each of them essentially provides for each party to itself have the right to attempt to exploit an opportunity within the AMI. To ensure that any such genre of AMIA does not violate the Competition Act civil provisions contained in sections 90.1, it will be critical that the applicable parties are able to show that despite any applicable restrictions on a party's ability to attempt to exploit an Opportunity within the AMI, the AMIA provides for potential collaboration on attempts to exploit Opportunities within the AMI going forward which may result in prospective joint ventures in regard to which risk sharing and efficiency gains by way of sharing of resources may be realized. In such event, it is our opinion that use of an AMIA would likely be legally permissible in Canada. 